\title{
Advances in remediation of heavy metal contaminated soil and water by Leersia hexandra Swartz
}

\author{
Hui Qin ${ }^{1,2,3}$, Hua $\operatorname{Lin}^{1,2,3,4^{*}}$ \\ ${ }^{1}$ Guangxi Key Laboratory of Environmental Pollution Control Theory and Technology, China \\ ${ }^{2}$ Guangxi Science and Technology Plan Project Lancang-Mekong Water Environment Technology Innovation Platform \\ (2018AD16013-04), China \\ ${ }^{3}$ Guangxi Science and Technology Plan Project (Guike AD17195023, Guike 2018AD16013), China \\ ${ }^{4}$ Guangxi Colleges and Universities High-level Innovation Team and Outstanding Scholars Program Project (Guicai Teaching Letter \\ [2018]319), and Guangxi Bagui Scholars and Specially Appointed Expert Projects, China
}

\begin{abstract}
Heavy metal pollution is extremely harmful to human beings. Looking for an efficient and environmentally friendly treatment method is the focus of current research. Using plants to treat contaminated water and soil has proven to be an effective and environmentally friendly method. Leersia hexandra Swartz is a chromium hyperaccumulator, and it can also enrich copper and nickel. Since the super enrichment characteristics of Leersia hexandra Swartz were discovered, many scholars have poured into the research on Leersia hexandra Swartz. This article will give an overview of the current application status of Leersia hexandra Swartz's purification of polluted water and soil, analyze the methods and principles used, and discuss the future development direction of Leersia hexandra Swartz's plant remediation technology.
\end{abstract}

\section{Introduction}

Chromium is a kind of heavy metal. A small amount of chromium can stimulate the growth of plants, but excessive chromium has a toxic effect on animals and plants, and has a significant carcinogenic and teratogenic effect on humans and animals [3]. The methods for removing heavy metal chromium in water and soil include physical method, chemical method, physical chemical method, etc. Among them, the phytoremediation technology has the advantages of low treatment cost and reduced site damage and has been generally valued. The use of super-enriched plants to treat contaminated water bodies and soil is also a core of plant remediation technology.

Leersia hexandra Swartz, Poaceae,a perennial herbaceous plant, widely distributed in southern China, mostly growing in wetlands, paddy fields or sandy shores [1]. Since Zhang Xuehong and others published "A Newly Discovered Wet-Generating Chromium Super Accumulating Plant-Leersia hexandra Swartz" in the Journal of Ecology in March 2006, Leersia hexandra Swartz's chromium superenrichment characteristics are well known. Leersia hexandra Swartz is a kind of chromium super-enriched plants. Super-enriched plants refer to plants that absorb heavy metals more than 100 times more than ordinary plants. This article introduces Leersia hexandra Swartz's current application in water treatment and soil remediation through a brief analysis of Leersia hexandra Swartz's principle of absorbing heavy metals, summarizes Leersia hexandra Swartz's environmental remediation capabilities, and mentions the shortcomings of the stage of research, and looks forward to the future development direction of Leersia hexandra Swartz's plant remediation technology.

\section{The principle of Leersia hexandra Swartz chromium absorption}

\subsection{The absorption mechanism of Chromium by Leersia hexandra Swartz}

The discovery of Leersia hexandra Swartz chromium super-enrichment characteristics is because it grows in large numbers near a pond near an electroplating industrial area in Guangxi, China, and shows strong tolerance to Cr. A sampling study by Zhang Xuehong's team found [2] that the chromium content of Leersia hexandra Swartz aboveground part was higher than that in the silt, especially the chromium content in the leaves was the highest, reaching $1084.2 \sim 2977.7 \mathrm{mg} / \mathrm{kg}$, and the average chromium content was $1786.9 \mathrm{mg} / \mathrm{kg}$, exceeding the critical value of plants for chromium superaccumulation $(1000 \mathrm{mg} / \mathrm{kg})$.

Chromium has two valence states: $\mathrm{Cr}^{6+}$ and $\mathrm{Cr}^{3+}$. Generally speaking, $\mathrm{Cr}^{6+}$ is more toxic to organisms than $\mathrm{Cr}^{3+}$. According to previous studies, $\mathrm{Cr}$ can be absorbed by plant roots in two forms: $\mathrm{Cr}^{6+}$ and $\mathrm{Cr}^{3+}$, and $\mathrm{Cr}^{6+}$ may be reduced to $\mathrm{Cr}^{3+}$ in the roots of plants [4]. Studies have found that metabolic inhibitors and low temperature can inhibit the absorption of $\mathrm{Cr}^{3+}$ by Leersia hexandra Swartz [1], while calcium ions and potassium channel inhibitors have no significant effect on the absorption of

\footnotetext{
*Corresponding author: linhua@glut.edu.cn
} 
$\mathrm{Cr}^{3+}$, indicating that Leersia hexandra Swartz's absorption of $\mathrm{Cr}^{3+}$ is related to potassium and calcium ions. The channel is irrelevant. Fe deficiency can promote the absorption of $\mathrm{Li}$ Shihe to $\mathrm{Cr}^{3+}$, while $\mathrm{Fe}^{3+}$ does not significantly change the maximum absorption rate Vmax of Leersia hexandra Swartz to $\mathrm{Cr}^{3+}$, but increases its Michaelis constant $\mathrm{Km}$. This indicates that the absorption of $\mathrm{Cr}^{3+}$ by the roots of Leersia hexandra Swartz may be partly carried out by the $\mathrm{Fe}^{3+}-\mathrm{PS}$ absorption system.

On the basis of the mechanism of Leersia hexandra Swartz absorbing $\mathrm{Cr}^{3+}$, Lu Yuanyuan [5] and others deeply explored the absorption mechanism of Leersia hexandra Swartz root on $\mathrm{Cr}^{6+}$. Through a series of experiments, the results show that ATPase inhibitors, uncoupling agents and low temperature can inhibit the absorption of hexavalent chromium by Leersia hexandra Swartz, indicating that the roots of Leersia hexandra Swartz may have a mechanism that can actively absorb Cr6+. The absorption of $\mathrm{Cr}^{6+}$ by $\mathrm{SO}_{4}{ }^{2-}$ and Leersia hexandra Swartz is a competitive inhibition. Because under the action of $\mathrm{SO}_{4}{ }^{2-}$, although the maximum absorption efficiency of Leersia hexandra Swartz's roots in absorbing $\mathrm{Cr}^{6+}$ has not changed significantly, the Michaelis constant corresponds to the experimental control group increased a lot, which means that the addition of $\mathrm{SO}_{4}{ }^{2-}$ can absorb Leersia hexandra Swartz's roots $\mathrm{Cr}^{6+}$ has an inhibitory effect.

Li Jianping [6] analyzed the mechanism of Leersia hexandra Swartz absorption of $\mathrm{Cr}^{6+}$ from the perspective of materials science. The surface morphology and element distribution of Leersia hexandra Swartz dry powder were characterized by scanning electron microscopy and X-ray energy spectroscopy. The results show that Leersia hexandra Swartz absorption of $\mathrm{Cr}^{6+}$ is a pseudo-second-order kinetic process of singlemolecule adsorption. The adsorption process includes two steps, $\mathrm{Cr}^{6+}$ The ions are concentrated on the surface of the dry powder material through electrostatic interaction, and then the functional coordination functional groups on the surface of the dry powder will chemically interact with $\mathrm{Cr}^{6+}$. In order to further investigate which kind of functional coordination functional groups on the surface of dry powder interact with $\mathrm{Cr}^{6+}$, Li Jianping's team combined with infrared spectroscopy to analyze and the results showed that there are a large number of carbonyl, hydroxyl, and amidecontaining structures on the surface of Leersia hexandra Swartz leaf cell dry powder. Functional groups have a certain direct in-situ reduction effect on the highly toxic $\mathrm{Cr}^{6+}$.

\subsection{Physiological response of Leersia hexandra Swartz under Chromium stress}

The production and elimination of reactive oxygen species in plant cells are in dynamic equilibrium under physiological conditions [7]. The toxicity of heavy metals to plants is mainly manifested in the large accumulation of active oxygen in the plant, a large increase in membrane peroxidation products, and the destruction of membrane structure [8]. The antioxidant effect of plants is the adaptive performance in the adversity environment. Plants form an antioxidant enzyme protection system in the long-term evolution process [9], which plays an important role in the process of removing reactive oxygen species, so that plants can tolerate, slow down or resist adversity stress to a certain extent [10]. Superoxide dismutase (SOD), peroxidase (POD), catalase (CAT), etc. are important antioxidant enzymes. SOD removes superoxide anions from cells, while POD and CAT remove $\mathrm{H}_{2} \mathrm{O}_{2}$ produced by SOD decomposition.

Yan Yan [11] studied the antioxidant enzyme system activity of Leersia hexandra Swartz and the changes of malondialdehyde content under chromium stress. By cultivating Leersia hexandra Swartz under different chromium concentration gradients, the following conclusions were drawn: 1 . With With the gradient of chromium stress mass concentration, the three antioxidant enzymes in Leersia hexandra Swartz first increased and then decreased, and peak values appeared when the mass concentration of $\mathrm{Cr}^{3+}$ was 40 $\mathrm{mg} / \mathrm{L}^{-1}$ and the mass concentration of $\mathrm{Cr}^{6+}$ was $20 \mathrm{mg} / \mathrm{L}^{-1}$. When the mass concentration of $\mathrm{Cr}^{3+}$ is $0 \sim 40 \mathrm{mg} / \mathrm{L}^{-1}$ and the mass concentration of $\mathrm{Cr}^{6+}$ is $0 \sim 20 \mathrm{mg} / \mathrm{L}^{-1}$, the three antioxidant enzymes in leaves, stems and roots act as endogenous active agents, which act synergistically to a certain extent. Beyond this mass concentration range, the antioxidant enzyme system is damaged and dysfunctional, resulting in decreased protective enzyme activity, loss of the function of scavenging active oxygen free radicals such as superoxide anion, aggravation of oxidative stress, and damage to plant cell membrane mechanisms and functions. 2. The content of MDA gradually increases with the gradient of chromium mass concentration. When the mass concentration of $\mathrm{Cr}^{3+}$ is $40-60 \mathrm{mg} / \mathrm{L}^{-1}$ and the mass concentration of $\mathrm{Cr}^{6+}$ is $20-60$ $\mathrm{mg} / \mathrm{L}^{-1}$, the MDA content increases significantly, and plants showed obvious symptoms of heavy metal toxicity.

\section{Leersia hexandra Swartz application in repairing heavy metal polluted water}

Leersia hexandra Swartz's compatibility is strong, and it can promote its water treatment effect by applying fertilizers and other substances, and it is also well combined with other environmental restoration methods to coordinate the treatment of polluted waters.

Nitrogen fertilizer is a frequently used fertilizer in agriculture. In order to explore the effect of nitrogen fertilizer on Leersia hexandra Swartz, Zhang Xuehong's research group added three different nitrogen fertilizers $\left(\left(\mathrm{NH}_{4}\right)_{2} \mathrm{SO}_{4}, \quad \mathrm{NH}_{4} \mathrm{NO}_{3}, \quad \mathrm{Ca}\left(\mathrm{NO}_{3}\right)_{2}\right)$ and a solution containing chromium ions when planting Leersia hexandra Swartz. Cultivate them, let them grow for a period of time and then harvest them to observe their biomass and metal ion accumulation. The results show that nitrogen fertilizer can significantly increase the biomass of Leersia hexandra Swartz, among which $\mathrm{NH}_{4} \mathrm{NO}_{3}$ has the most obvious effect [12]. In terms of 
promoting the absorption of chromium ions by Leersia hexandra Swartz, the aboveground part and roots of applying $\left(\mathrm{NH}_{4}\right)_{2} \mathrm{SO}_{4}$ are higher than applying $\mathrm{NH}_{4} \mathrm{NO}_{3}$, and the least promoting effect for Leersia hexandra Swartz is $\mathrm{Ca}\left(\mathrm{NO}_{3}\right)_{2}$. Zhang Chenchen also used a similar method to study the effect of nitrogen fertilizer on Leersia hexandra Swartz absorption of copper ions, and the results showed that nitrogen fertilizer also had the same promotion effect on Leersia hexandra Swartz absorption of copper ions [13].

Nitrogen, phosphorus, and sulfur are common nonmetal nutrient elements in the soil. Nitrogen fertilizers have been confirmed in previous studies to promote the absorption of chromium by Leersia hexandra Swartz. In order to further explore the effects of non-metal elements in the soil on Leersia hexandra Swartz, Wu Chancui and others cultivated uncontaminated Leersia hexandra Swartz seedlings for a certain period, and divided the plants into 7 groups, and then each group added different reagents. The results of this experiment show that $\mathrm{NO}_{3}-$ will compete with hexavalent chromium for absorption sites, so nitrogen deficiency will help Leersia hexandra Swartz absorb hexavalent chromium[14]; the addition of $\mathrm{SO}_{4}{ }^{2-}$ will help Leersia hexandra Swartz absorb hexavalent chromium Produce competitive inhibition. However, phosphorus deficiency will affect the absorption of Leersia hexandra Swartz, so appropriate addition of $\mathrm{H}_{2} \mathrm{PO}_{4}$ - will help Leersia hexandra Swartz to absorb hexavalent chromium.

Wang Wenping and others started from the influence of calcium ions and glyoxylic acid on the absorption of chromium ions by Leersia hexandra Swartz, and explored whether these two factors can promote Leersia hexandra Swartz's absorption mechanism. Calcium is an essential element for plants, and has a messenger function that couples extracellular signals and intracellular physiological and biochemical reactions, and plays an important role in the process of plant signal transmission [15]. The previous research of Wang Wenping's group found that the concentration of calcium ions will significantly affect the synthesis of oxalic acid in Leersia hexandra Swartz, and the coordinated combination of chromium and oxalic acid may be an important part of Leersia hexandra Swartz detoxification mechanism of chromium[16]. The results of this experiment are as follows: insoluble oxalic acid may be harmful Enrichment of chromium plays a major role. The increase in calcium ion concentration will increase the secretion of oxalic acid in plants and reduce the content of malondialdehyde in plants. That is to say, under a certain concentration range of chromium stress, high calcium treatment of Leersia hexandra Swartz can reduce the toxicity of chromium to plants and enhance its ability to absorb chromium ions.

Glyoxylic acid may be the direct precursor for Leersia hexandra Swartz to synthesize oxalic acid [17], and previous experiments have proved that the increase of oxalic acid can strengthen Leersia hexandra Swartz's ability to enrich and tolerate chromium. Relevant experimental results showed that under the stress of chromium, compared with the control group, the root length, plant height and biomass of Leersia hexandra
Swartz treated with glyoxylic acid were higher than those of the control group, indicating that glyoxylic acid can enhance Leersia hexandra Swartz. The growth under chromium stress alleviates the toxicity of chromium to Leersia hexandra Swartz.

In addition to nitrogen fertilizer, calcium ions and glyoxylic acid that can promote Leersia hexandra Swartz treatment of chromium-containing heavy metal wastewater, the emerging constructed wetlands can also be combined with Leersia hexandra Swartz to treat water polluted by heavy metals. Tao Jixun uses Leersia hexandra Swartz constructed wetland to remove heavy metals in electroplating wastewater. The filler of the constructed wetland is zeolite and red soil, and Leersia hexandra Swartz is planted above the filler area. The final result of the experiment shows that the removal rate of chromium, copper and nickel in the wastewater from the Leersia hexandra Swartz constructed wetland reached $86.76 \%, 95.52 \%$ and $78.34 \%$, respectively. The filler area [20] plays a major role in the absorption of heavy metals. One result may be because the removal mechanism of heavy metals in constructed wetlands is the result of matrix adsorption, plant absorption, and heavy metal sedimentation [18]. The main role is matrix adsorption, and plant absorption is a very small part.[19].

After the Leersia hexandra Swartz constructed wetland system was proved to be able to effectively remove heavy metals in water, $\mathrm{Gu}$ Chen and $\mathrm{Wu}$ Qingxin did further research. Gu Chen also used zeolite and red soil as the substrate of constructed wetland to study the purification ability of Leersia hexandra Swartz constructed wetland system for domestic sewage containing heavy metals. The experiment found that the removal efficiency of the Leersia hexandra Swartz constructed wetland for wastewater containing multiple heavy metals is better than that of a single heavy metal, and it can also degrade ammonia nitrogen and total phosphorus in domestic wastewater [21]. Within a certain range, the higher the concentration of ammonia nitrogen and total phosphorus in domestic sewage, the more conducive to Leersia hexandra Swartz absorption of hexavalent chromium and nickel, but it will reduce the absorption of copper ions. Wu Qingxin uses XPS and other material analysis methods combined with organic matter content, $\mathrm{pH}$, Eh and $\mathrm{Cr}$ mass balance analysis to study the purification mechanism of the Leersia hexandra Swartz constructed wetland on $\mathrm{Cr}^{6+}$-containing waters [22]. The experimental results show that Leersia hexandra Swartz increased the organic matter content in the wetland matrix, thereby improving the purification capacity of the wetland system for $\mathrm{Cr}^{6+}$. Organic matter as an electron donor participates in the reduction of $\mathrm{Cr}^{6+}$ by the wetland matrix, making it better absorbed by the matrix.

\section{Leersia hexandra Swartz's application in soil remediation}

The heavy metal polluted water body undergoes sedimentation, and finally is enriched in sludge or migrates to the soil with water flow and irrigation [24], 
thereby polluting the soil. In order to study the remediation efficiency of Leersia hexandra Swartz on soil chromium pollution and the effects of continuous harvesting, fertilization and EDTA on the restoration efficiency of Leersia hexandra Swartz, Leersia hexandra Swartz was buried in chromium-containing soil and cultivated in a greenhouse [1], and regularly watered during the cultivation period. The relevant experimental conclusions are as follows: Regarding the use of Lee's grass for soil chromium pollution remediation, for the initial concentration of $200 \mathrm{mg} / \mathrm{kg}$ and $300 \mathrm{mg} / \mathrm{kg}$ of chromium-contaminated soil, to remediate it to the relevant standards, the Leersia hexandra Swartz needs to be harvested 11 times. And 25 times. This shows that it is feasible to directly plant Li's grass to remediate soils with moderate or light chromium pollution. The results of continuous harvesting research on Leersia hexandra Swartz show that multiple harvests within one year did not reduce the biomass and chromium-enrichment capacity of Leersia hexandra Swartz ground, and can also stimulate the growth of Leersia hexandra Swartz. Therefore, Leersia hexandra Swartz can be harvested continuously to repair heavy metals. Pollute the soil. The effects of fertilization and EDTA on Leersia hexandra Swartz are just the opposite. Fertilization has a positive effect on Lee's remediation of soil chromium pollution, while EDTA will reduce Leersia hexandra Swartz ability to repair chromium-contaminated soil.

Zhang Xuehong and others once again studied the tolerance and repair ability of Leersia hexandra Swartz for a single copper-contaminated soil [24], the final result showed that Leersia hexandra Swartz can absorb copper ions in the soil. And it has certain resistance to copper and can survive high concentration of copper ion treatment. However, from the point of view of copper adsorption capacity and other parameters, Leersia hexandra Swartz cannot be called a copper hyperaccumulator, but it can also be used to repair soil contaminated by copper. Tao Jixun et al. studied Leersia hexandra Swartz absorption of copper, chromium and nickel in soil contaminated by electroplating sludge. The experimental results show that Leersia hexandra Swartz can grow normally in soils with $\mathrm{Cr}, \mathrm{Cu}$, and $\mathrm{Ni}$ contents of $8515.69,3442.27$, and $2992.55 \mathrm{mg} \cdot \mathrm{kg}-1$, and can adsorb and degrade heavy metal ions, It fully shows its potential in remediation of heavy metal soil [23].

Humic acid is a very important organic matter in the soil. Through complexation, adsorption and oxidation-reduction reactions with heavy metals, humic acid changes the shape of the soil and the soil's ability to absorb heavy metals, affecting its effectiveness and plant absorption [25]. Wang Jiansheng et al. [26] studied the effect of the interaction between humic acid and chromium on the growth and photosynthetic physiology of Leersia hexandra Swartz. It is found through experiments that Leersia hexandra Swartz can grow well in low concentration $\mathrm{Cr}$ contaminated soil. At the same time, under the Cr-contaminated soil, the dry mass of each part of Leersia hexandra Swartz increased with the increase of humic acid concentration. Under $200 \mathrm{mg} / \mathrm{kg}$ $\mathrm{Cr}$ contaminated soil, Leersia hexandra Swartz did not show obvious toxic effects, and the addition of humic acid can also improve the dry quality of Leersia hexandra Swartz.

\section{Summary and Prospect}

Originally considered to be farmland weeds, Leersia hexandra Swartz has become a research hotspot in the field of heavy metal pollution prevention because of its biological characteristics of drought resistance, submergence tolerance and barren tolerance and its super-enrichment of heavy metal chromium [27]. Before Leersia hexandra Swartz's chromium hyperaccumulation characteristics were discovered, there were no reports of chromium hyperaccumulation plants in China.

In addition to its chromium super-enrichment characteristics, Leersia hexandra Swartz can also enrich copper and nickel ions in water or soil, and even absorb TN, TP, NH3-N, and CODMn in eutrophic water. Significantly [28]. These studies have provided great help to Li's application in the prevention and control of heavy metals. At present, it is known that nitrogen fertilizers, glyoxylic acid, calcium ions, humic acid and other external factors that promote the absorption capacity of Leersia hexandra Swartz, as well as the influence of natural conditions such as light and temperature, and the artificial wetland system.

Titanium dioxide is a semiconductor material that can perform photocatalytic oxidation by absorbing light energy. It is currently commonly used to purify water, improve battery life, and manufacture antibacterial medical materials. Guan Wei et al. [30] applied for an invention patent in 2017, which uses an electrolytic cell with titanium dioxide as the anode and graphite as the cathode to reduce hexavalent chromium in wastewater and oxidize hypophosphite. The advent of this invention patent has made a big step forward for the research in the field of titanium dioxide. The titanium dioxide electrolytic cell has the characteristics of reducing hexavalent chromium, and may be combined with Leersia hexandra Swartz to purify wastewater polluted by hexavalent chromium. The combination of this new type of electrolytic cell of titanium dioxide and Leersia hexandra Swartz has great application prospects.

In addition, there is plant microbial fuel cell technology. Plant microbial fuel cell (PMFC) is a new technology that combines plants, microorganisms and electrochemical elements to create renewable energy [29]. Currently, there are few data on applying this technology to the treatment of heavy metal pollution. PMFC can not only degrade heavy metals in water bodies, but also output bio-electricity to enhance its water purification capabilities. This technology can be combined with Leersia hexandra Swartz to treat chromium-polluted water bodies.

\section{References}

1. X.H. Zhang, Ricerca sulla tecnologia di fitormediazione del suolo contaminato da metalli pesanti. Science Press, 2011. 
2. X.H. Zhang, A newly discovered wet chromium hyperaccumulator plant-Leersia hexandra Swartz. Acta Ecologica Sinica.2006, 26 (3) : 950-953.

3. C. Hu, Study on the enrichment and detoxification mechanism of Leersia hexandra Swartz on chromium. Guilin University of Technology,2008.

4. Zayed A, Lytle C M, Jin-Hong Q, et al.Chromium accumulation, translocation and chemical speciation in vegetable crops. Planta, 1998, 206: 293-299.

5. Y.Y. Lu, Study on the mechanism of Cr(VI) uptake by the roots of the hyperaccumulator plant Leersia hexandra Swartz. Journal of Agricultural Environmental Sciences.2013, 32 (11) : 21402144.

6. J.P. Li, Study on the adsorption characteristics of chromium(VI) on the dry powder of leaf cells of the hyperaccumulating plant Leersia hexandra Swartz. Journal of chemical.2008, 66 (23) : 2646-2652.

7. L. Wang, H.L. Yi, Effect of $\mathrm{SO}_{2}$ Stress on the Activity of Antioxidant Enzymes in Arabidopsis. The ecological environment.2007, 16(6): 16121614

8. Mishra NP,Misha RK, Singlral GS. Changes in the activities of anti-oxidant enzymes during exposure On intact wheat leaves to strong visible light at different temperatures in the preasence of protein synthesis inhibitors . Plant Physiology,1993, 10. 2: 903-910

9. B.Y. Wang, S. Liu, P. Liu,Response of Antioxidant System in Wheat Leaves to Aluminum Stress. The ecological environment.2006, 15(4): 818-821

10. Camp WV ,Capiau KC , Montagu MV,'et a1. Enhancement or oxidatives stress tolerance in transgenic tobacco plants overproducing Feuperoxide dismutase in cell oroplasts . Plant Physiology,1996; 1 (12) : 1703-1714

11. Y. Yan, Physiological response of Leersia hexandra Swartz induced by chromium and electrochemical behavior of simulated biofilm. Guilin University of Technology.2009.

12. X.H. Zhang, Effect of Nitrogenous Fertilizer Forms on the Concentration of Chromium in Leersia hexandra Swartz and Its Biochemical Analysis. Journal of Guilin University of Technology.2011, 31 (3) : 399-403.

13. C.K. Zhang, Effects of Nitrogen Fertilizer Forms on the Enrichment of Copper by Leersia hexandra Swartz and Its Physiological Response.Journal of Eco-Environment.2017, 26 (9) : 1599-1604.

14. C.C. Wu, Effects of Nitrogen, Phosphorus, and Sulfur on the Absorption of $\mathrm{Cr}(\mathrm{VI})$ by the Chromium Hyperaccumulator Leersia hexandra Swartz.Jiangsu Agricultural Sciences.2019 (14) : 316-320.
15. RuddJ. J. , FrankLin-TongV. E. Unravelling response specificity in $\mathrm{Ca} 2+$ signaling pathways in plant cells. New Phytol, 2011, 151(1): 7-33

16. W.P. Wang, Regulating effect of calcium on the accumulation of Leersia hexandra Swartz and chromium tolerance.Journal of Environmental Engineering.2013, 7 (12) : 5012-5018.

17. W.P. Wang, Experimental study on the influence of glyoxylic acid on the tolerance and enrichment of Leersia hexandra Swartz chromium.Safety and environmental engineering.2014, 21 (1) : 12-16.

18. C.X. Song, J.F. Niu, Y. Quan, The physiological mechanism and progress of phytoremediation of harmful metals in the environment.Chemical equipment technology.2004, 25(2): 56-58.

19. Z.Q. Zhao, X.M. Xiang, Y.S. Li, Research on the role ofplants in sewage land treatment.Environmental Science Research.2000, (5): 54-57.

20. J.X. Tao, Experimental Research on Removal of Heavy Metals in Electroplating Wastewater by Leersia hexandra Swartz and Its Constructed Wetland.Guilin University of Technology.2009.

21. C. Gu, Experimental study on the purification of heavy metal-containing domestic sewage by Leersia hexandra Swartz and its constructed wetland.Guilin University of Technology.2013.

22. Q.X. WU, J. Liu, S.H. You, Study on the Mechanism of Leersia hexandra Swartz Wetland System Purifying Cr(VI) Polluted Water.Journal of Environmental Science.2014,34( 9) : 2306-2312.

23. J.X. Tao, Leersia hexandra Swartz absorption and accumulation of chromium, copper and nickel in soil contaminated by electroplating sludge.Journal of Guilin University of Technology.2010, 30 (1) : 144-147.

24. X.H. Zhang, Study on the characteristics and resistance of Leersia hexandra Swartz to copper accumulation in soil. Anhui Agricultural Sciences.2008, 36 (13) : 5586-5587, 5590.

25. L. Guo, Y.S. Bu, Effect of coal-based humic acid on corn growth and physiological characteristics under exogenous arsenic stress.Journal of Environmental Engineering.2014, 8(2) : 758-766.

26. J.S. Wang, Effects of soil chromium pollution and humic acid on the growth and photosynthetic physiology of Leersia hexandra Swartz.Jiangsu Agricultural Sciences.2019, 47 (5) : 263-267.

27. D. Li,Research Progress and Application Status of Leersia hexandra Swartz.Anhui Agricultural Sciences.2014, 42 (6) : 1671-1673, 1794.

28. H. Cheng, Research on the Purification Effect of Leersia hexandra Swartz on Different Degree of Eutrophic Water Body.Water treatment technology.2019, 45 (3) : 120-124. 
29. Chung-Yu Guana, Yi-Ho Tsenga, Daniel C.W. Wetland plant microbial fuel cells for remediation of hexavalent chromium contaminated soils and electricity productio.Journal of Hazardous Materials 365(2019):137-145

30. W. Guan, Metodo per ossidare simultaneamente l'ipofosfito nelle acque reflue di cromatura e ridurre il cromo esavalente. China. 